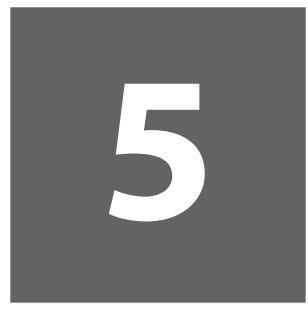

\title{
Career Progression in Hospitality and Tourism Settings
}

\author{
Adele Ladkin and Aliaksei Kichuk
}

\section{Learning objectives}

After reading this chapter you will be able to:

- Understand the characteristics of tourism and hospitality employment

- Define careers and career development

- Explore the way individuals build careers in tourism and hospitality

- Explain the relationship between career development and talent management

\section{Introduction}

This chapter considers the career journey that individuals make in hospitality and tourism settings, and the role of talent management in the career development process. Career development is facilitated both by organisations in terms of their current and future human resource needs, and by individuals who make choices concerning their career needs and aspirations. Career development plans and prospects take place in numerous industry sectors, each with their own labour market characteristics and norms for career development opportunities.

In this chapter, the nature of tourism and hospitality employment is outlined as a starting point to set the context of careers in the tourism and hospitality sectors. This is followed by an exploration of the aspects that are relevant to the topic: careers, career development and career progression. The career journey then becomes the focus of discussion, outlining what constitutes a career journey before examining them in the tourism and hospitality contexts. The remaining part of the chapter turns its attention to talent management in the career context. The relationship between talent management and careers is outlined. A summary is then offered. 


\section{Tourism and hospitality employment}

The ever-growing tourism sector provides opportunities for employment creation. Estimates by the World Travel and Tourism Council anticipate that over the next ten years there will be 347 million tourism jobs worldwide (World Travel \& Tourism Council, 2014). Tourist activities create direct, indirect and induced employment opportunities. As discussed elsewhere by Ladkin and Szivas (2015), direct employment refers to employment in tourist sectors such as hotels, tour operators, transport, travel agencies etc. Indirect employment refers to jobs created by people working in activities that are partially dependent on tourism, for example, financial services, construction, car hire, etc. Induced employment is the additional employment resulting from the effects of the tourism multiplier as residents spend money on activities earned from tourism (Fletcher et al., 2013). What this provides is a wealth of employment opportunities in numerous sectors, some more directly related to tourism and hospitality settings than others.

In terms of employment issues and labour markets, information is more readily available concerning the hospitality sector, partially due to jobs in this sector being more evident and less hidden than those in tourism. In the UK, for the tourism and hospitality sectors, figures from People 1st for 2013 indicate that:

The sector accounts for just over 2 million jobs

Restaurants employ the largest workforce in the sector

$35 \%$ of businesses expect the workforce to increase

By 2020, the sectors' workforce will have grown by $6 \%$

An additional 660,200 people will need to be recruited by 2020

Nearly half of the workforce is part-time

The sector has a young workforce, two in five workers are aged under 30

$57 \%$ of the sector are female

$32 \%$ of employers have female senior managers

$22 \%$ of the workforce are migrant workers

(People 1st, 2013, p11)

Despite the diversity in the tourism and hospitality sectors, it is possible to identify certain characteristics of employment in the sectors. These broad characteristics have been identified and discussed elsewhere (Duncan et al., 2013; Janta et al., 2011), however a selection of these are presented here as they require consideration due to their relevance to how people develop their careers in the sectors. The characteristics that have an influence on career development include:

Tourism and hospitality occupations vary widely in terms of skill requirements, ranging from unskilled to highly skilled and professional occupations. This presents a range of opportunities for different skill levels, and provides a means for up-skilling throughout a career journey.

As appears as in: Horner, S., ed. Talent Management in Hospitality and Tourism. Oxford, UK: Goodfellow

Publishers. ISBN 978-1-910158-67-8. http://www.goodfellowpublishers.com/talent 
Many of the occupations have low barriers to entry (Liu and Wall, 2005; Vaugeois and Rollins, 2007). For example, if they are unskilled or semi skilled, they are open to a wide range of people and may be seen as a 'first job' to gain experience. This can be drawback, creating the perception of low skilled, low paid menial transient jobs (WTTC, 2014). However, it could also be viewed as a positive aspect as it means that many jobs are open to everyone. Unskilled or low skilled jobs provide the entry points for work into the sectors.

The contractual arrangements are varied, for example they may be parttime or full-time, permanent, temporary or seasonal. This again can be viewed both as positive or negative. Positive in that the flexibility of contracts suits different individual needs, but negative as the security of full-time permanent work is not always available.

Some of the occupations have clear career progression, others do not. The lack of clear career pathways is one of the main reasons leading to a poor image of the sectors and the negative impact of this on recruitment (WTTC, 2014).

Turnover rates can be high (Yang, 2010). One feature of the sector that is felt in most countries and appears to be universal is higher turnover rates compared to occupations in other sectors.

The sector is one that employs economic migrants due to the ease of obtaining employment in the sectors. (Matthews and Ruhs, 2007; Janta et al., 2011). A low skill specificity, few educational requirements and short term contracts make many of the jobs available to a wide range of individuals. High turnover also ensures a constant supply of available employment opportunities for migrant workers seeking their first job in a new country.

Associated poor labour conditions conform to stereotypes and are well documented, consisting of issues such as low pay, shift work, long hours,

and poor career advancement opportunities (Baum, 2007; McIntosh and Harris, 2012).

Cultural and social issues in some countries make travel and tourism less attractive than other sectors. For women, this may place a 'glass ceiling' on their participation rates (WTTC, 2014).

\section{Careers, career development and progression}

\section{A career}

A career is the "evolving sequence of a person's work experiences over time" Arthur, Hall and Lawrence (1989: 8). The traditional understanding of a career is seen in terms of professional employment with progression and advancement in the organisational position (Gunz and Heslin, 2005). However, traditional concepts 
of a career based on organizational structures and hierarchies are in decline (Eaton and Bailyn, 2000; Sullivan, 1999) and are being replaced by careers with less developed structures. The modern career is multi-dimensional, developing beyond the constraints of a single organization or occupational setting (Arthur, 1994; Collin and Young, 2000). It is associated with increased mobility and is increasingly 'boundaryless' (Arthur, Inkson and Pringle, 1999, p 11) reflecting contemporary work practices.

However defined, careers are the outcome of structural opportunities available to an individual, for example the size of the industry, organizational structure, and knowledge requirement, human ability and ambition. The structural opportunities in an industry provide the framework for any occupation, and individual ability and ambition determine how people make choices within the structural opportunities (Ladkin and Weber, 2009). From an individual's perspective, how people's experiences and occupations change across a life course is essentially what defines a career.

Within the broad field of career theory, career development and progression form an integral aspect.

\section{Career development}

Career development is closely aligned with career planning. It is an essential component of human resources management (Nebel, Braunlich and Zhang, 1994). In the organisational context, career development is concerned with:

How individuals manage their careers within/between organisational structures;

How organisations structure the careers of their members.

From a personal perspective, career development is concerned not only with how individuals manage their careers, but also how individuals view and direct their own careers in terms of their goals, values, beliefs aspirations etc.

Essentially, labour market and structural opportunities are presented by the industry context but it is a range of personal choices, opportunities and constraints that make one person's career different from others.

As careers are part structure, part individual choice, we can argue that the responsibility for career development rests neither solely with the individual nor the organisation, but is shared by both (Pazy, 1988, Orpen, 1994). It is the outcome for the individual from both organizational and personal career planning (Simonsen, 1986). It is widely accepted that joint responsibility is the best way to achieve successful career development (Kong et al., 2010; Lewis and Arnold 2012). Both organisational needs and personal career goals can be considered together and be mutually beneficial. This practice is in line with contemporary ways of working, as individuals are now less likely to spend all of their working lives with a single organisation. 


\section{Career progression}

Career progression is a term that is often used in discussions of career development. It can be taken loosely to mean the process of making progress towards better jobs, implying an upward trajectory. As individuals gain more experience, they take on more challenging roles and responsibilities, usually rewarded with higher levels of pay. Implicit in progress through a career is the assumption of ever improving occupations and status. One factor that significantly affects career progression is that some careers have clear progression routes, and these are largely professional careers, for example, as in the case of a medical practitioner or an airline pilot. Other careers follow a much less well defined route, developing in a more ad hoc way with greater fluidity and variability. This is certainly the case for many tourism and hospitality careers, and will be returned to later in the chapter.

\section{The career journey}

In recognition of the many structural and individual factors that impact upon a person's career, one way in which an individual's career development can be explored is through the career journey. As implied by 'journey' we are concerned with how a career develops going from one job to another over time.

There is little doubt that the career journey looks quite different now to the past (Arthus, Inkson and Pringle, 1999). As discussed earlier, traditional career development largely took place within one organisation, and was characterised by a series of structured job changes with an upward trajectory. They were based on hierarchical, highly rigid structures (Baruch, 2004). Hall (2004) discusses the shift towards a protean career, characterised by proactive career management by the individual and involving multiple job and organisational changes. Related to this is the concept of the boundaryless career, advocated by Arthur (1994). In this type of structure, a career is not limited to one organisation but involves many different organisations and occupations. The implication is that careers cross multiple boundaries, the corporate boundaries of hierarchy and status, occupational, trade and job boundaries of specialist skills and function, and alongside this the social boundaries of separating work from home are no longer applicable (Arthur, Inkson and Pringle, 1999: 11).

Career journeys therefore can no longer be seen as following a one directional route, but take on different forms according to the changing structures of labour markets and individual choice and opportunity. This type of career journey is possible where there are opportunities in both the internal and external labour markets, as individuals make the most of opportunities offered by their existing employer or in moving to a new one. This type of mobility will have an impact on turnover if there are more job moves in the external rather than the internal labour market. This notion of a more fluid career structure is useful to set the context of 
career journeys in the tourism and hospitality settings, where these characteristics are evident.

\section{Career journeys in tourism and hospitality settings}

Tourism and hospitality employment involves a multitude of different activities, types of establishments, working arrangements and employment contracts. The diversity of the industries provides a wide range of job opportunities, which are difficult to categorise. One consequence of this is that the choice of career path opportunities is bewildering.

There are many different ways in which the tourism and hospitality industries are classified, providing an indication of the vast array of job opportunities. For example, the Office of National Statistics (2016) identifies that following industry groups for employment purposes:

Accommodation for visitors

Food and beverage activities

Passenger transport, vehicle hire, travel agencies etc.

Cultural, sports, recreational and conferences etc.

People 1st (2013) has these hospitality employment categories:

Events

Food and service management

Gambling

Hospitality services

Hotels

Pubs, bars and nightclubs

Restaurants

Self catering accommodation, holiday parks, and hostels

Tourist services and

Visitor attractions

The type of organisation for employment opportunities is vast, including for example airlines, cruise ship operators, rail companies, coach companies, tour operators, travel agents, theme parks, cafes, museums, resorts, hotels, restaurants etc. Added to this myriad of employment sectors are the various job functions, including for example sales and marketing, food and beverage, accounting, finance and purchasing, human resources management, information technology and systems, education, customer services and generic leadership and management.

Given the importance of human resources to the tourism and hospitality industries, surprisingly little is known about how people develop careers in these sectors. There are some exceptions, one being the case of hotel managers in which there is a wealth of research (Guerrier 1987, Baum 1988, Riley and Turam 1989, 
Ladkin and Riley, 1994, 1995, 1996, Ladkin, 1999; 2002). One of the reasons for this body of research is that the hotel sector presents one of the more structured employment sectors in terms of a developmental hierarchy. Medium to large hotel companies offer a range of different functions for employment (for example front office, food and beverage, human resources management, finance and accounting, sales and marketing, housekeeping etc.) and recognised job levels (for example, operative, supervisor, department section head, department head, assistant manager, deputy general manager, general manager). The occupation of hotel general manager is widely seen in the industry as a target job, and one that attracts commitment to the career, therefore undertaking career tracking surveys is possible for this occupation. The nature of the hotel industry suggests that career patterns of hotel managers are likely to involve mobility (Ladkin and Riley, 1996). This mobility is both between and within organisations, but showed little movement outside of the hotel sector. In a related sector, this has been supported by McCabe and Savery (2007) who through an exploration of the careers of professional conference organisers, employees in hotels and convention, identified a new career pattern, which they named 'butterflying'. This term refers to having more than one career route through different sectors, where respondents flutter between sectors according to the opportunities of employment and career growth. In essence, individuals make the most of job opportunities as they arise to facilitate their career development. There is no one specified career journey, but rather the journey is opportunistic, and in some ways reflects an extension of the boundaryless career McCabe and Savery, 2007). However, traditional careers that follow an upward trajectory were also evident (Kong et al., 2011; Wang, 2013).

Specifically in terms of career development, previous studies in the context of hospitality (Ladkin, 1999; 2002) and the events industry (McCabe, 2008) have explored a range of career choice and development issues. These confirm that the tourism and hospitality sectors have few structured career opportunities. Often occupations are seen as transitory, with many people working in the sector for short periods of time and with notions that it will only be temporary (Ladkin, 2013). Those who intend to remain in the sector, may become frustrated by the lack of career opportunities and therefore do not remain.

\section{Careers and their relationship with talent management}

Despite the wealth of research from the hospitality field on the topic of talent management (Lashley et al., 2007; Barron, 2008; Baum 2008; Hatum 2010; Steward and Harte, 2010; Collings and Mellahi, 2009; Kalaisevan and Naachimuthu, 2011) very little is known about the relationship between talent management and careers. In tourism, there is a dearth of talent management discussion, beyond the recognition that the loss of talented individuals is a significant problem for the industry (Ladkin, 2013). In hospitality, talent management is largely confined to discussions around talent management practices and activities (Kichuk, Ladkin,

As appears as in: Horner, S., ed. Talent Management in Hospitality and Tourism. Oxford, UK: Goodfellow

Publishers. ISBN 978-1-910158-67-8. http://www.goodfellowpublishers.com/talent 
and Horner, 2014). Broadly, discussion focuses on attraction, selection, development and retention of talented individuals (Watson, 2008).

This is not surprising, as the existence of talent is important for the sustainability of organisations. Optimising talent is instrumental in determining whether the organisation is successful or not. The importance of talent in a people based industry is paramount (Sonia and Neetu, 2012; Watson, 2008) and without a doubt, hospitality organisations have to retain the best and brightest talents in order to succeed (Tuglan, 2001). Hotels continue to operate in an environment that is often unpredictable and characterised by rapid seasonal change (Poescu and AvramRatiu, 2012). Specific industry challenges include labour shortages both in terms of quality and quantity (Sonia and Neetu, 2012), a lack of skilled candidates for leadership positions (Pricewaterhouse Coopers, 2012) and the negative employer image that can lead to difficulties of attraction to the industry (Hughes and Rog, 2008). The reliance on temporary and or migrant workers can also be problematic in terms of labour turnover (Janta and Ladkin, 2009). Essentially, developing and managing talent in hotels is bound within the nature of the hospitality industry. High mobility, short term contracts, the employment of a large percentage of low or semi skilled workers, and problems of recruitment and retention all have an impact (Kichuk, Ladkin and Horner, 2014).

Aligning career progression to the talent management is now seen as a priority (Sparrow et al., 2011). Career management practices could be designed to assist the career development of employees as well as considering organisational needs (Kong et al., 2010). Essentially, this widens the traditional requirement of talent management for the benefit of the organisation, to consider how talent management will also benefit individuals and enable them to better plan and manage their careers. While talent management is widely used by organisations' human resource departments to enable organisational goals for recruitment, retention and development of vital employees (Stahl et al., 2007), it is important to remember that individuals join organisations to develop and fulfil their own careers (Panda and Sahoo, 2015). In recognition of the duality of needs from both the organisation and the individuals, the narrow scope of talent management as purely organisational human resource practices is contested. Thunnissen et al. (2013a, 2013b) advocate for talent management to also consider the aspirations, needs and preferences of individual employees and their career development.

Organisational human resource current and future needs and the experiences and aspirations for the personal career development of employees is the basis of the relationship between talent management and careers.

\section{Attracting and retaining talent through career development}

The tourism and hospitality sectors are facing a problem in terms of attracting and retaining talent (WTTC, 2014). Talented employees are recognised as vital for ensuring the success of organisations (Kusluvan et al., 2010) with organisations paying particular attention to how they might attract, retain and develop

As appears as in: Horner, S., ed. Talent Management in Hospitality and Tourism. Oxford, UK: Goodfellow

Publishers. ISBN 978-1-910158-67-8. http://www.goodfellowpublishers.com/talent 
the careers of talented individuals (Cappelli and Keller, 2014). Attracting the right employees can lead to better customer service, and cost efficiency where turnover is reduced (Bharwani and Butt, 2012).

People $1^{\text {st }}$ (2015) have outlined the concerns of the growing skills gap and high turnover rates in the tourism and hospitality sectors. The number of employers in this sector with vacancies has increased from 16\% in 2011 to $18 \%$ in 2013, with those vacancies that are considered 'hard to fill' rising by $12 \%$ in the same timeframe (UKCES, 2013). Recruitment appears to be getting more problematic, with reasons given for this including the low number of applicants with required skills, attitude and motivation; a lack of work experience; not enough interest in the sector; and an unwillingness to undertake jobs that have shift work and/or unsociable hours (UKCES, 2013). High turnover rates are continually driven by the sector's overreliance on young workers, migrant workers, flexible contracts and low pay (People $\left.1^{\text {st }}, 2015\right)$.

In response to this on-going problem, there are a number of responses by employers to both attract and retain talent. This include flexibility in working arrangements, work design practices to make work more challenging and varied, and employee engagement. However, given the characteristics of the sector and the nature of many jobs, this is problematic.

The implementation of career development practices is also seen as a way forward. For example, strategies that motivate employees by job design and reward (Clayton, 2006) and those that develop marketable skills and feelings of value to the organisation (CIPD 2014). Specific career development strategies to attract and retain talent from an organisation perspective include:

In-house training programmes

Coaching and mentoring opportunities

Job rotation

Work-shadowing.

However, often the high labour turnover rates act as a barrier for organisations to invest in staff, only to lose them later on.

The Manpower Group talent shortage survey (2014) identified that human resources management should focus on three areas: people practices, talent sources, and work models. Examples of each include clear development opportunities during recruitment, providing training for existing staff, recruiting from outside the region and patterning with educational institutions to align skill requirements and to take the best from education, and redesigning work procedures offering more flexible working arrangements.

Recent research by Ladkin and Buhalis (2016) has advocated the use of online and social media recruitment as one of the ways to facilitate recruitment. A web presence can formulate an identity for organisations through brand awareness and reputation, as a means to attract talented employees.

As appears as in: Horner, S., ed. Talent Management in Hospitality and Tourism. Oxford, UK: Goodfellow

Publishers. ISBN 978-1-910158-67-8. http://www.goodfellowpublishers.com/talent 
The skills shortage and problems of recruiting and retaining talent individuals for the tourism and hospitality sectors look unlikely to be solved in the near future. However, due to the positive benefits that talented individuals bring to the workplace, any mechanism to foster the process has to be considered. An improvement in defining career development routes and training opportunities represents one positive strategy to attract and retain employees.

\section{Summary}

This chapter has sought to explore the career journeys that individuals make in tourism and hospitality settings. The value of career progression and development for individuals has been highlighted, along with the role that talent management might play in these processes. Due to the structure of the tourism and hospitality sectors, there is no one set career development route, which is one of the reasons for the difficulty in attracting and retaining individuals. There is considerable choice in terms of employment opportunities in the sectors, a shortage of applicants for many jobs, along with predicted growth in the sectors. These factors combined present the opportunity for employment and positive job prospects. Recruiting and encouraging people to develop careers in the sector is crucial. Incorporating talent development practices as part of career development programmes may be one of the ways forward.

\section{Learning activities}

The following activities can be undertaken in the form of small group discussion to facilitate an understanding of jobs and career development in the tourism and hospitality sectors.

1 Have you ever worked in any of the tourism and hospitality sectors? Think about the job you did, and reflect on a) the skills you needed to be able to perform your work, and b) what the opportunities were for further training and career development.

2 Many of the jobs in the tourism and hospitality sectors are customer facing. What do you consider to be important skills for being able to undertake customer-facing roles and deliver excellent customer service?

3 Reflect on the characteristics of the tourism and hospitality labour force. For employers, what are the challenges in providing career pathways for people who wish to develop a career in these fields?

4 Consider how a career is defined and reflect on how career development and career paths have changed over time.

5 Identify different talent management practices that could be used to assist career development in the tourism and hospitality sectors. Consider how talent management practices might be utilised by a) employers and b) individuals.

As appears as in: Horner, S., ed. Talent Management in Hospitality and Tourism. Oxford, UK: Goodfellow

Publishers. ISBN 978-1-910158-67-8. http://www.goodfellowpublishers.com/talent 


\section{Assessment suggestions}

6 Design a questionnaire that would help organisations understand the career development needs of the different employees in their organisations.

7 Write a report that identifies different talent management strategies, and how they might be used to benefit both the organisational and the individual.

8 Write an essay on the following. "Identify and discuss the characteristics of tourism and hospitality sector employment and the challenges they present for attracting and retaining talent."

\section{References}

Arthur, M. B., (1994). The boundaryless career: A new perspective for organizational inquiry. Journal of Organizational Behaviour, 15, 295-306.

Arthur, M. B., Hall, D.T. and Lawrence, B.S. (1989). Handbook of Career Theory. Cambridge University Press. Cambridge.

Arthur, M.B., Inkson, K. and Pringle, J.K. (1999). The New Careers. Individual action and economic change. Sage, London.

Barron,P. (2008). Education and talent management: Implications for the hospitality industry. International Journal of Contemporary Hospitality Management, 20(7): 730-742.

Baruch, Y. (2004). Transforming careers from linear to multidirectional career paths. Organizational and individual perspectives. Career Development International, 9(1),58-73.

Baum, T. (1988) Ireland: Toward a new definition of hotel management. Cornell Hospitality Quarterly, 29(2): 35-40.

Baum. T. (2007). Human resources in tourism: Still waiting for change. Tourism Management 28(6), 1383-1399.

Baum,T. (2008). Implications of hospitality and tourism labour markets for talent management strategies. International Journal of Contemporary Hospitality Management, 20(7), 721-729.

Bharwani, S. and Butt, N. (2012). Challenges for the global hospitality industry: an HR perspective. Worldwide Tourism and Hospitality Themes, 4(2), 23-37.

Cappelli,P. and Keller, J.R. (2014). Talent management: Conceptual approaches and practical challenges. Annual Review of Organizational Psychology and Organizational Behaviour, 1,305-331.

CIPD (2014). Learning and Development. Annual Survey Report 2014. Chartered Institute of Personnel and Development. London.

Collin, A. and R.A. Young, R.A. (2000). The future of careers. In The Future Career, Cambridge: Cambridge University Press.

Collings, D.G. and Mellahi, K. (2010). The barriers of effective global talent management: The example of corporate elites in MNEs. Journal of World Business, 45,143-149 
Clayton, G. (2006). Key skills in retention and motivation: the war for talent still rages and retention is high ground. Industrial and Commercial Trading, 38(1), 37-45.

Duncan, T., Scott, D G. and Baum, T. (2013). The mobilities of hospitality work: An exploration of issues and debates. Annals of Tourism Research, 41(1), 1-19.

Eaton, S.C. and Bailyn, L. (2000). Career as life path: tracing work and life strategies of biotech professionals. In Career Frontiers: New Concepts Of Working Lives, edited by T. Morris. (pp.177-198). Oxford: Oxford University Press.

Fletcher, J., Fyall, A., Gilbert, D. and Wanhill, S. (2013). Tourism Principles $\mathcal{E}$ Practice, $5^{\text {th }}$ Ed. Pearson Education Limited, Harlow.

Guerrier, Y. (1987). Hotel managers' careers and their impact on hotels in Britain. International Journal of Hospitality Management, 6(3), 121-130.

Gunz, H.P. and Heslin,P. A. (2005). Reconceptualising career success. Journal of Organizational Behaviour. 26,105-111.

Hall, T. (2004). The protean career: A quarter-century journey. Journal of Vocational Behavior. 65(1), 1-13.

Hatum, A. (2010). Next Generation Talent Management. Talent Management to survive turmoil. Basingstoke: Palgrave Macmillan.

Hughes, J. C. and Rog, E. (2008). Talent Management: A strategy for improving employee recruitment, retention and engagement within hospitality organisations. International Journal of Contemporary Hospitality Management, 20(7),743-757.

Janta, H. and Ladkin, A. (2009). Polish migrant labour in the hospitality workforce: Implications for recruitment and retention. Tourism, Culture and Communication. 9(1/2), 5-15.

Janta, H., Ladkin, A., Brown, L. and Lugosi,P. (2011). Employment experiences of Polish migrant workers in the UK hospitality industry. Tourism Management, 32(5), 1006-1019.

Kalaiselvan, K. and Naachimuthu, K.P. (2011). A synergic model to training and development. The Indian Journal of Industrial Relations, 47(2), 366-379.

Kichuk, A., Ladkin, A. and Horner, S. (2014). Understanding talent management in hospitality: A career perspective? CHME Annual Research Conference, University of Derby, May.

Kong, C., Cheung, C. and Zhang, H.Q. (2010). Career management systems: what are China's state-owned hotel practising? International Journal of Contemporary Hospitality Management, 22(4), 467-482.

Kong, H., Cheung, C. and Song, H. (2011). Hotel career management in China: Developing a measurement scale. International Journal of Hospitality Management, 30, 112-118.

Kusluvan, S., Kusluvan, Z., IIhan, I. and Buyruk, L. (2010). The human dimension: A review of human resources management issues in the tourism and hospitality industry. Cornell Hospitality Quarterly. 51(2), 171-214.

Ladkin, A. (1999). Hotel general managers: A review of prominent research themes. International Journal of Tourism Research, 1(3), 167-193. 
Ladkin, A. (2002). Career analysis: a case study of hotel general managers in Australia. Tourism Management 23(4), 379-388.

Ladkin, A. (2013). Tourism human resources. In C. Costa, E. Panyik and D. Buhalis (Eds). Trends in European Tourism Planning and Organisation. Channel View Publications. Bristol.

Ladkin, A. and Buhalis, D. (2016). Online and social media recruitment: hospitality employer and prospective employee considerations. International Journal of contemporary Hospitality Management, 28(2), 327-345.

Ladkin, A. and Riley, M. (1994). A research update, Tourism Management, 15(3), 221-222.

Ladkin, A. and Riley, M. (1995). Hotel management careers: Research update 2. Tourism Management. 16(6), 475-476

Ladkin, A. and Riley, M. (1996). Mobility and structure in the career paths of UK hotel general managers: A labour market hybrid of the bureaucratic model? Tourism Management, 17(6), 443-452.

Ladkin, A. and Szivas, E. (2015). Green jobs and employment in tourism. In M.V. Reddy, and K. Wilkes (Eds). Tourism in the Green Economy. Routledge, Taylor and Francis Group, Oxon. 115-127.

Ladkin, A. and Weber, K. (2009). Career analysis of convention professionals in Asia: The case of Hong Kong. In T. Baum, M. Deery, C. Hanlon, L. Lockstone and K. Smith (Eds). People and Work in Events and Conventions: A research perspective. CABI: London. 39- 50.

Lashley, C., Lynch,P. and Morrison, A., (2007). Hospitality: A social lens. Elsevier: Oxford.

Lewis, S. and Arnold, J. (2012). Organisational career management in the UK retail buying and merchandising community. International Journal of Retail and Distribution Management, 40(6), 451-470.

Liu, A. and Wall, G. (2005). Human resources development in China. Annals of Tourism Research 32(3), 689-710.

Matthews, G. and Ruhs, M. (2007) Are you being served? An exploration of the demand for migrant labour in the UK's hospitality sector. Working Paper No. 51. University of Oxford, Oxford.

McCabe, V. and Savery, L. (2007). 'Butterflying' a new career pattern for Australia? Empirical evidence. Journal of Management and Development, 26(2),103-116.

McCabe, V. (2008). Strategies for career planning and development in convention and exhibition industry in Australia. International Journal of Hospitality Management, 27(2), 222-231.

McIntosh, A and Harris, C. (2012). Critical hospitality and work: (In)hospitable employment in the hospitality industry. Hospitality and Society 2(2), 129-135.

Manpower Group (2014). Manpower Group 2014 Talent shortage Survey Results: Available at www.manpoergroup.co.uk/media/137404/2014_talent_shortage_wp_us2.pdf

Nebel, E. C., Braunlich, C.G. and Zhang, Y. (1994). Career paths in American luxury hotels: Hotel food and beverage directors. International Journal of Contemporary Hospitality Management, 6(6), 3-9. 
ONS (2016). Characteristics of tourism industries, 2014. Office for National Statistics. $3^{\text {rd }}$ February. Available at www.ons.gov.uk Accessed 3 ${ }^{\text {rd }}$ April 2016.

Orpen, C. (1994). The effects of organizational and individual career management on career success. International Journal of Manpower, 15(1), 27-37.

Panda, S. and Sahoo, C.K. (2015). Strategic talent development interventions: an analysis. Industrial and Commercial Training, 47(1), 15-22.

Pazy, A. (1988). Joint responsibility. The relationship between organizational and individual career management and the effectiveness of careers. Group and Organizational Studies, 13(3), 311-331.

People $1^{\text {st }}$ (2013). State of the National Report 2013. Available at http://www.people1st.co.uk/ research/state-of-the-nation-2013 (Accessed 14 ${ }^{\text {th }}$ April 2016).

People $1^{\text {st }}$ (2015). The skills and productivity question: Hospitality and tourism sector. http:// www.people1st.co.uk/getattachment/Research-policy/Research-reports/The-Skills-andProductivity-Problem/Report-The-Skills-and-productivity-problem-Oct-15.pdf.aspx

Poescu, C. and Avram-Ratui. (2012). New trends in resource management in the hospitality industry. International Conference of Scientific paper AFASES, 2-6.

Pricewaterhouse Coopers (2012). Delivering results through talent - the hr challenge in a volatile world. $15^{\text {th }}$ Annual Global CEO Survey. Available at: www.pwc.com/talent management

Riley, M. and Turam, K. (1989). The career paths of UK hotel managers: A developmental approach. Signet Quarterly, 1(1), 1-13.

Thunnissen, M., Boselie,P. and Fruytier, (2013a). Talent management and the relevance of context: Towards a pluralistic approach. Human Resources Management Review, 23(4), 326-336.

Thunnissen, M., Boselie,P. and Fruytier, (2013b). A review of talent management: infancy or adolescence? International Journal of Human Resource Management 24(9), 1744-1761.

Simonsen,P. (1986). Concepts of career development. Training and Development Journal, 40(1): 70-74.

Sonia, B. and Neetu, B., (2012). Challenges for the global hospitality industry: An HR perspective. Worldwide Hospitality and Tourism Themes, 4(2), 150-162.

Sparrow,P., Hird, M. and Balain, S. (2011). Talent Management: Time to question the Tablets of Stone? White paper 11/01, October, Lancaster University Management School.

Stahl, G.K., Bjorkman, I., Farndale, E., Morris, S.S, Paauwe, J., Syiles,P., Trevor, J. and Wright,P. M. (2007). Global Talent Management: How leading multinationals build and sustain their talent pipeline, INSEAD Faculty and Research Working Papers.

Steward, J. and Harte, V. (2010). The implications of talent management for diversity training: an exploratory study. Journal of European Industrial Training, 34(6), 506-518.

Sullivan, S.E. (1999). The changing nature of careers: A review and research agenda. Journal of Management, 25(3), 457-484.

As appears as in: Horner, S., ed. Talent Management in Hospitality and Tourism. Oxford, UK: Goodfellow

Publishers. ISBN 978-1-910158-67-8. http://www.goodfellowpublishers.com/talent 
Tuglan, B., (2001). Winning the talent wars. Employment Relations Today, 23(1/2), 37-51.

UKCES (2013) UK Commission Employer skills Survey 2013: UK results Evidence Report 81. London: UK Commission for Employment and Skills www.ukces.org.uk/publications

Vaugeois, N. and Rollins, R.(2007). Mobility into tourism: Refuge employer, Annals of Tourism Research, 34(3), 630-648.

Wang, Y.F. (2013). Constructing a career competency model of hospitality industry employees for career success. International Journal of Hospitality Management, 25(7), 994-1016.

Watson, S. (2008). Where are we now? A review of management development issues in the hospitality and tourism sector, International Journal of Contemporary Hospitality Management, 20 (7), 75.

World Travel and Tourism Council (2014). Global Talent Trends and Issues for the Travel E Tourism Sector. London. Oxford Economics, London.

Yang, J.T. (2010). Antecedents and consequences of job satisfaction in the hotel industry. International Journal of Contemporary Hospitality Management 29(4), 609-619. 